CRITICAL REVIEW ARTICLE

\title{
Critical Readings of Franz Kafka's The Trial
}

Ayila Orkusa

University of Nigeria, Nsukka, Nigeria

\begin{abstract}
The Trial (1925) yields to interpretations within and outside the literary circles and the general view has been that the text is obscured. This popular submission has affected scholarly attention on the text, but this does not dissuade critical studies on the text. This study engages critical readings of The Trial, paying attention to the theoretical and conceptual frameworks that have formed the grounds of being for such readings, as well as topical and thematic issues in the text. Thus, this paper answers the question on the techniques of studying The Trial. The recent and less recent works on The Trial respectively give attention to both material and nonmaterial worlds as captured in the text. This study explores the historical, philosophical, and formalistic views on The Trial as captured in various studies. The conclusion is that the knowledge of The Trial as a literary text possible through a close reading, even though several readings have treated it as the author's commentary on his own society. Such readings take a position that the text offers an interpretation of a certain human society somewhere. Yet some of the critical readings treat the text as art and generate literary discourses from it.
\end{abstract}

Keywords: readings, critical, modernist, literature, Kafka

\section{Introduction}

Franz Kafka's The Trial has received adequate critical attention. Such critical studies have followed different patterns that sometimes reflect unconnected themes but they all work towards appreciating or assessing the text as literature. No doubt, much efforts have been made to derive meaning from the text for moral judgment, sometimes social standards have been applied to read the text; passing the text through the lens of social realism. In most cases such efforts have been shown to some extent to be futile as the text often show a break away from the general assumptions that literature mirrors society. The critical concern that apparently surrounds such readings is, what can one do with this text? But it must be understood that The Trial is a literary text and the formal aspect of it must not be abandoned in favour of "comments on man and the human" (Akwanya, 2018, p.16), an ethical approach that dominates literature today. The supposed claim about lack of connection between social values and codes within the text is responsible for the general indictment that the text is 
obscured. In this study it has become obvious that such indictment stems from a reductionist approach to art, which avoids the essential question that is fundamental to literary criticism.

This study randomly explores the critical readings of The Trial to see that "Art, particularly literature, is unlike anything else that human beings make or deal with, because it looks over the entirety and the depth of human existence as well as regarding realms outside it, producing interpretations and meanings with or without the support of evidence" (Akwanya, 2018, p.27). So some studies in this paper have shown that the reality in The Trial is independent of social reality anywhere else in the real world. Yet other studies draw attention to the social facts that have to some extent become historical facts. Such readings simply acknowledge that the facts of history can become artefacts for literary creation. At a glance this study provides the two views on literature: the ethical view as promoted by Plato and the essential view advanced by Aristotle. It is from this ethical views that critics have engaged the study of society or source study in the text.

\section{Discussion and Analysis}

\subsection{Source Study}

Richard Posner makes a review of the Franz Kafka's: The Office Writings with emphasis on the relationship between Kafka's professional life as a lawyer in an insurance firm and Kafka as a writer of literature (Posner, 2010, p.206). Posner holds that Franz Kafka: The Office Writings bear immeasurably and unprecedented depth on the fictional works of Kafka. However, Posner notes a methodological problem in this text (Posner, 2010, p.208). He observes that there is no discussion on the translators' approach to their translation of Kafka's office writings from German to English. Posner's position here does not imply doubt in the translation, but simple questions the methodology of the translation.

Despite what Posner sees as a limitation on Franz Kafka's: The Office Writings, he focuses on establishing a link between Kafka's real life and his fiction. Posner has shown instances where Kafka's fictions borrow from his real life. The scene of execution of Joseph $\mathrm{K}$. at the quarry, for instance, Posner says is borrowed from Kafka's report on quarry incidents and generally, the parody of the law and bureaucracy in The Trial and The Castle are expressions of Kafka's frustration in his official writing for the institution where he worked (Posner, 2010, p.213).

Unlike Posner, who explores only the relationship between Kafka's office writings and his fiction, Stanley Corngold and Ruth V. Gross later examine beyond the relationship between the office writings of Kafka and his fiction, into judicial proceedings in The Trial. In their introduction to Kafka for the Twenty-First Century, Corngold and Gross argue that 'Many prominent cases figure in the pages of Westlaw... in which the sufferings of the accused appear to have leapt from the pages of The Trial and are acknowledged as such' (Stanley Corngold and Ruth V. Gross, 2011, p.2). They emphasize that the models of judicial proceedings in The Trial are found in contemporary American courts, especially where accused people are tried in a language they don't understand, while others are tried and condemned in absentia (Corngold and Gross, 2011, p.2). Corngold and Gross say that the importance of Kafka is not just in the volume of citation he has provoked, but also by having 
attracted endless interpretation and as such criticism of Kafka cannot fail to be instructive. These critics have, however followed Posner's argument, contending that there is a relationship between Kafka's office work as a lawyer in an insurance company and his fiction.

Corngold and Gross affirm that Kafka's office writing moves spectrally through his fiction (Corngold and Gross, 2011, p.7). They also point out that even 'Kafka's protagonists are always playing the role of representatives, proxy figures as we find in Joseph K. who mounts a platform during his own interrogation to speak on behalf of those whose pleas go unheard in the court' (p.13). This for Corngold and Gross is another point of symbiotic relationship between Kafka's work life and his literary engagement and thought. Because Kafka's protagonists' representative positions reflect Kafka himself, as he held the proxy power that warrant him to validate documents that he didn't authored, not even read. And his protagonists perform such functions at different capacities in different texts. "They do so by performing actual proxy-like acts, presuming to stand in for whole classes of men" (Corngold and Gross, 2011, p.13).

The above concern with the relationship between Kafka's office life and his fiction is given further attention by Doren Densky. Densky compares Kafka to the protagonists in The Trial, Joseph K. He holds that Kafka's position in real life as a proxy who functions as Koncipist (law clerk or legal secretary) echoes in his fiction. In his fictional world of The Trial, Kafka assigns this proxy role to Joseph K. as a Prokurist (Densky, 2011, p.121). Densky is of the view that there is a relationship between Kafka's first briefs in Jurisprudence and some passages in The Trial; that shows there is a link between the narrative voice and the author. He says, proxies populate all of Kafka's fictional works.

Densky posits that there is a structural transformation from the administrative writing of the Koncipist (Kafka) to the acting of fictional Prokurist (Joseph K.), and common to both is that they are surrounded by a legal and bureaucratic authority that is always deferring, complex and inscrutable (Densky, 2011, p.121). To support his position that K. is a Prokurist, a proxy, Densky points at "The manufacturer's use of a double or even triple titles for Joseph K. - as 'Prokurist', "K.," and "practically a lawyer" - leads to the core of K.'s proxy status, with each identification, referring to a different facet of what it means to be a stand-in" (2011, p.128). In a detailed analysis of the function of Prokurator and the legal struggles in The Trial involving K., Densky says, “K.'s legal representative Advokat Huld is of little help; it is mostly up to $\mathrm{K}$. himself to assume the position of being his own defender, which leads to the attempt to prepare his written defence, an overview of his life" (2011, p.128).

Apart from Joseph K. being a proxy, Densky says that his referent, letter ' $\mathrm{K}$ ', which is the initial of his last name is representational (2011, p.129). This to Densky explains why K. becomes an identity for several of Kafka's other protagonists. Joseph K. and Kafka, Densky asserts, "take on the perspectives of observers and commentators who are equally involved and uninvolved in the issues at stake" (2011, p.132), in their various functions.

Reza Banakar like Corngold and Gross, fully consider the concept of law in the works of Kafka. It is worthy of note that the relationship between Kafka's office writings and his 
fiction dominate these readings, particularly that of Posner, Corngold, Gross, Banakar and some others. Banakar draws our attention to the priest in the Cathedral, in The Trial, who tells Joseph K. that the "right perception of any matter and a misunderstanding of the same matter do not wholly exclude each other" (Banakar, 2010, p.464). Thus, Banakar argues that:

Kafka's technique of conflating the "right" perception of a matter with the reverse of its everyday logic — a technique that is the hallmark of Kafka's rhetoric — needs to be understood in the discursive context of his work as a lawyer. The legal aspects of Kafka's work do not, admittedly, explain his linguistic imagination, but they do throw new light on the link between law and his images of legality. (2010, p.464)

Banakar uses sociological concepts, Gemeinschaft and Gesellschaft to explain the alienating effects of the impersonal relations characteristic of the Gesellschaft in The Trial. The result is that alienation leaves Joseph K. an exile in his own home town (2010, p.466). Again, Banakar describes Joseph K. as someone "fully aware of his right and possesses the working knowledge of law... yet he at the same time appears to be a complete outsider to the law and its process" (2010, p.478). Banakar holds that there is a fusion of forms of law in the works of Kafka and to understand this fusion, one must turn to Kafka's office writing. Thus, Banakar compares Joseph K. in The Trial to Joseph Franz Renelt, the owner of an orchard and quarry in The Office Writing to show that Kafka's creative imagination is actually linked to his life work as a lawyer in the insurance company.

As Renelt encounters insurance law and criminal law, the accused Josef K. - who, like Renelt before the Aussig district court, "is not in custody" - tries to identify the jurisdiction he is dealing with. His later reflections on his strange trial could be regarded as a copy of Renelt's successful shift of focus from the factual to the procedural aspects of the legal dispute and its ensuing transformation into an out of court settlement: in a deleted passage of Kafka's last novel, The Castle, we find a comment on the vain struggle for physical possession of written evidence that occurred in yet another phase of Renelt's matters. (Banakar, 2010, p.481)

Banakar says both protagonists in The Trial and The Castle appear as victims because Kafka's tale has taken a viewpoint. Banakar submits that Kafka's concept of "law and legality is diffused in the practice of double thoughts" which is presented to us through a conflation of rational with non-rational, the mundane with extraordinary, rendering obsolete any concept of law (2010). Banakar posits three summations in his study of Kafka thus: (1) Kafka's conflation of the rational and the irrational in his works is an inherent paradox of modernity. (2). In the workings of the paradoxes, Kafka presents us with insider and outsider points of view about the law and bureaucracy. (3). That Kafka's fiction is parallel of a state legal system against which one cannot defend oneself (Banakar, 2010, p.483-4).

\subsection{Religion}

Bruce K. Ward employs Rene Girard's analysis of the victim mechanism in 'Giving Voice to Isaac: The Sacrificial Victim in Kafka's Trial' to unravel the enigmatic nature of Joseph K. in The Trial. He argues that Kafka offers us in The Trial "the prophetic portrait of a victim who is... exceptional, but who is not exemplary for other human beings" (Ward, 2004, 
p.65). Ward thus compares Kafka's Joseph K. to Dostoevsky's Dmitri Karamazov, arguing that the contrast between the two characters is from the influence of Judaism on Kafka, which shapes his artistic revelation of the modern sacrificial victim (2004, p.65). Ward considers some possible readings of The Trial but none of such readings could justifiably prove that K's. imperfection deserves the type of death, which he died. Thus, he submits that:

This humiliating death with which the novel concludes destroys finally all the nice symmetries of poetic justice that might be applied to K.'s fate. The simple fact is that imperfect though he doubtless is - somewhat egotistical, somewhat manipulative of women, somewhat self-satisfied, somewhat mediocre and bourgeois in his ambitions - K.'s final punishment of death under a butcher's knife is out of all proportion to these imperfections. He does not deserve such an end. (Ward, 2004, p.67)

Ward observes that K's. execution disrupts the symmetry required by the strictly rational conception of retributive justice. He uses George Steiner's words, saying that, "The Trial preeminently, articulates an overwhelming feat of metaphysical-religious imagining and enquiry" (2004, p.67). Ward thus reads The Trial after the pattern of Rene Girard's reading of Job and says that the perplexities presented by Job can be brought to bear also on the perplexities presented by The Trial (2004, p.69). In this light, Ward adjudges K. as an innocent victim, who has fallen victim to a persecution mechanism, a social mechanism that has selected him as its victim (2004, p.71). Ward holds that K. himself succumbs to the perspective of his persecutors because he does not condemn their idea of retributive punishment; rather his interest at every point is to reform it (2004, p.74). After observing K.'s reaction on the scene where two wardens are punished for pilfering K.'s underwear and his interaction with the executioner, Ward takes a position that "Joseph K. is an exceptional victim, but he is not an exemplary victim" (2004, p.75). Ward concludes that in The Trial Kafka does not promise to represent the idea of hope through suffering, and for Ward this is the extreme influence of Judaism on Kafka.

\subsection{Modernist Perspectives on The Trial}

A. Kiarina Kordela and Dimitris Vardoulakis take a different approach in their study of The Trial, however, like in the other preceding works, they reflect on Kafka's life and profession in relation to his fiction. In their introduction to Freedom and Confinement in Modernity: Kafka's Cages, they submit that Kafka's literary world is organized imprisonment, such that most of his protagonists are not free (Kordela \& Vardoulakis, 2011, p.1), and Joseph K. in The Trial for instance has been found guilty without any named charge against him. Kordela and Vardoulakis hold that the traditional interpretation of confinement in Kafka's works would link to Kafka's personal experience with his father, his job and his relationship with women on the one hand. On the other hand, the arbitrary confinement in Kafka is 'conceptualized as a wider metaphysical or religious quest to show the fallen world of modernity in which man is trapped in his complete separation from spirituality' (2011, p.1). However, they break away from the traditional interpretation of imprisonment and confinement in Kafka's oeuvre and posit that imprisonment, cage (as they call it) is rather, 
The very critique of a culture that first posits a clear-cut opposition between confinement and freedom, and then sets up freedom as an ideal, which, conceived in such absolute terms, is by definition unattainable. In its laborious and exhilarating pages, Kafka's work probes the arsenal of the configurations through which such a culture reduces freedom to the bait whose promise and impossibility torment people. (Kordela \& Vardoulakis, 2011, p.2)

They argue that encagement in Kafka gives his work cultural resonance in his time to the present (2011, p.3). The collection centres on understanding cages in Kafka works.

In another essay, A. Kiarina Kordela asserts that The Trial is based on mergence of the distinction between empirical realm and unconditional transcendental law (Kordela, 2011, p.140). This brings to us the idea of humanity and divinity dissolving into one. She spells out three intertwined relationships that are characteristic of The Trial and other works of Kafka as: no entrance, no exit, and the third is but the maze itself which Kordela says:

The first two are presupposed for the third principle: finally, even as-if not precisely because - there is neither entrance nor exit, one is outside the cage. 'The Cell' presents us with a partly austere world behind whose doors there is nothing but 'a dark, smooth rock-face . . . extending vertically upwards and horizontally . . . seemingly without an end,' and partly with an opulent, albeit equally hermetic 'royal apartment.' Yet, these two parts do not form a whole; as the narrative voice abruptly informs us: 'that was not all'. (Kordela, 2011, p.140)

She argues that Kafka's cage is paradoxical, such that "one can be confined in only by being outside" (2011, p.141). Kordela gives an insight on guilt in The Trial through her focus on one of the narrator's statement, "It was as if the shame of it must outlive him". Kordela draws our attention to the fact that the statement negates the status of the state described, meaning the guilt did not outlive him. So, the feeling that the guilt outlived him is a fetishist illusion that holds its victim in guilt (2011, p.141). Kordela ends by saying that there is a permeative uncertainty that frustrates the desire to know certain empirical reality about The Trial since 'nothing aids us in deciding for or against depicted appearance' (2011, p.142).

Similar to what Kordela and Vardoulakis did, Chris Fleming and John O'Carroll explore the levels of imprisonment in The Trial at four major levels, including legal arrest, social containment, humiliation and linguistic entrapment. They argue that given the modernist presentation of the world, the novel is not equivocal regarding the protagonist's guilt or innocence. Rather, it presents cues that allow critical reading "to see orders of guilt and innocence, and to form judgment on that basis" (Fleming \& O'Carroll, 2011, p.30). Fleming and O'Carroll give us the context of the modernist that frames The Trial and the relationships to Joseph K.'s kinds of imprisonment. Some of this modernist framing includes Kafka's compelling of readers to grasp the world through the constricted, humiliated points of view of the protagonists. They again say that 'Kafka's protagonists are often disoriented, mistaken about reality, and uncertain about what even the near-term future holds' (2011, p.30). The lack of grasp on their (the protagonists') world, Fleming and O'Carroll say, affects the readers who also eventually dimly understand the texts as the protagonists. Again, like 
other critics, they have acknowledged the moral complexity and the fragmentary nature of the text with a dream logic that goes beyond their comprehension (2011, p.30).

Fleming and O' Carroll draw readers' attention to Kafka's expression of lack of selfhood, which modern sociologists 'describe in terms of disorientation, loss of centre, loss of certainty' (2011, p.32). They argue that trial and imprisonment in Kafka's thought are the same. Though Joseph K. is not physically confined behind bars, he is under a form of confinement, which includes:

(1) an arrest; (2) a series of court demands made upon him; (3) a variety of soft sanctions and social hostility and disapproval; (4) an apparent inability to communicate in the language of his interrogators; (5) the processes of judgment themselves require K. to perform in ways to which he is profoundly unaccustomedand his own personality in this sense becomes the thing that limits his performance; and (6) his freedom-but not his personal liberty-is restricted. (Fleming and O’Carroll, 2011, p.47)

They further argue that the imprisonment of K. is in levels: first, the physical imprisonment that startles him in bed and his eventual execution. Secondly, K's. imprisonment is how the trial has changed his behaviour "in response to the official demand", and thirdly, the society's response to his arrest. The fourth level "concerns the way language works, or rather fail to work", for instance, at the beginning of the text when the wardens ignored $\mathrm{K}$. and refused to answer his question about his arrest. "The fifth level of imprisonment, and indeed of trial, forces Josef K. - and his reader - to think about performance in the actual trial itself." The sixth level of imprisonment/trial "concern the disjunction between freedom and liberty" (2011, p.35). Fleming and O'Carroll state that:

If we take this dimension as the end point of the novel, then we could contend that the "trial/imprisonment" of the protagonist is a case of free will being assessed, of his acute failure to act in a personally principled way, and a condemnation as a result of the fact that he does not exercise his liberty in a way deserving of freedom. $(2011,36)$

Fleming and O'Carroll follow René Girard's victim mechanism like Bruce K. Ward, who did earlier studies on The Trial and affirm that Joseph K. is simply a scapegoat, a victim who does not go without his own personal guilt (2011, pp.39-40). They add that "scapegoats do not have to be innocent to be scapegoat"'(2011, p.42). They conclude that Joseph K.'s primary error resides "in his evident delusion that he is an agent at all" (2011, p.42), and above all, "The Trial offers us a portrait of a peculiarly modern form of victimhood, that occurring within the context of oppressive and amoral forms of bureaucratic rationality" (2011, p.43).

Lubomir Doležel in "Intensional Function, Invisible Worlds, and Franz Kafka", employs the theory of macro-intentional to make sense of the visible and invisible world in which Joseph K. operates. He holds that while Kafka's works have been given critical attention, the investigation of its semantic macro-structuring has been generally neglected (1983, p.128). He says that Kafka's works, particularly The Trial and The Castle lack textual and extra-textual information about the indeterminate domain and therefore the domain becomes an invisible world (1983, pp.128-9). 
Doležel says that Kafka's semantic macrostructure in the two novels (The Trial and The Castle) is realized through the positioning of the fictional world into a visible domain and an invisible domain so, a study of the invisible world will unravel the principles of sense organization characteristic of Kafka's fiction (1983, p.130). Doležel elaborates four aspects of the relationship between the visible and the invisible world, which include: 1. Mutual exclusivity of the two worlds; 2 . The invisible world is inaccessible from the visible world; 3 . The invisible world is in the position of power vis-a-vis the visible world and; 4 . The visible world is a world of social institutions (1983, pp.130-135). Doležel emphasizes that human law is diametrically opposite to natural law and Kafka has shown through art that social activities have interplays between human law and natural law (1983, p.135).

Keith Fort in "The Function of Style: Franz Kafka's The Trial" argues that many years of studies on The Trial have brought about points of agreement on the meaning of the novel except that the 'court' remains enigmatic and makes Kafka unreal and mysterious (Fort, 1964, p.643). For Fort, Joseph K. represents this mystery because through him we make meaning of the novel, but we could not understand the reality of the world in which $\mathrm{K}$. is. Fort says that K. seems to be in two worlds, the world of the bank and the world of the court, a point which Doležel had earlier on hinted on (Doležel 1983, p.130). So, Fort's position seems to be a confirmed statement of fact. However, Fort does not focus on the two worlds in Kafka's The Trial. Rather, she underscores the reversal of order in the modern world where style determines value. She says, "Every time a modern author puts pen to paper he must redefine reality" (1964, p.646). In other words, modern authors do not accept pragmatic reality as the essential quality of objects. Fort states further that the world of the Bank is 'real' and its pragmatic reality imitates an accustomed way of looking at life. Nevertheless,

The court is composed of the same objects that make up the world in which K. lives. It is the same world which we recognize so easily when its reality is defined within the bounds of the pragmatism to which we are accustomed. But it becomes the court when it is looked at in a new way and its reality is redefined. This redefinition occurs when K. reflects upon his daily life and sees that its essence is not the harmless, even benign, reality which he assumed it to be. (Fort, 1994, p.648)

In Fort's argument, Joseph K.'s relationship with the bank and the court divides him into two personalities: the functionary and the human being. Fort further explains her position that the court remains hidden to the readers because since style defines reality in relation to value, Kafka writes "from within total anxiety caused by the absence of value" (1964, p.648). So, K.'s reasoning and relationship with the court have affinities with the subconscious than the conscious. Therefore, “K.'s mind defines his life in terms of the court, but he does not himself necessarily understand the meaning of that definition" (1964, p.648). Fort describes The Trial as an extended metaphor in which Kafka presents 'K.'s world in court' (1964, p.650).

Steve Antinoff' examines the influences of The Trial on the modern and postmodern world. He holds that arrest in Kafka's The Trial explains Kafka's view about life. The arrest is not physical, but existential. "The arrest, evidently, is not by the police (the Inspector is 
never seen again), but self-arrest, the arrest that occurs not because of any specific act, but by being a self in the world. To be, for Kafka is to be under arrest" (Antinoff, 2009, p.354). Antinoff sees Kafka's idea of arrest-within-movement which is central to The Trial as a metaphor to discuss cutting edge in the twenty-first century dance. He compares the ambiguous concept (arrest-within-movement) to Zen Koan that is in its nature antithetical. Antinoff describes Kafka as:

the true genius of constriction in the West, who situated the human crisis in the very attempt to move, and then struggled with the full deployment of his artistic and existential forces to escapee this fix - knowing with each sentence he wrote he was all the more boxed in. (2009, p.357)

Antinoff shows a connection between The Trial and Zen Koan to demonstrate that no movement can settle the inner disturbance to the human heart, and he connects this to the movement in dance which implies a dilemma that is caused by the fact of being alive (360).

Philip Rahv's study also implicates modernity as he argues that The Trial and The Castle are Kafka's creation from within to outwards of its personal elements (Rahv, 1939, p.60). He describes Kafka as "an enigmatic figure in modern letters... [whose work] does not depend on definitive logic... no body of knowledge external to itself... he is not allegorical in any accepted sense, but rather an innovator so deeply individualistic as to fit none of the familiar categories" (Rahv,1939, p.61). Rahv shows that The Trial has the knowledge of itself and not of any external world. For him Kafka belongs to none of the existing categories of the allegorists. He stresses the enigmatic nature of Kafka's works, pointing out that Kafka's mystification is not in style, but in meaning (1939, pp.61-2.

Rahv holds that "The Trial and The Castle are built on the themes of guilt and are enormous projection of self-punishment, of imagined wrongdoing and atonement" (1939, p.66). Thus, nothing can be done to atone for the unnamed guilt. Rahv also gleaned from the biographical materials, diaries, notebooks, and letters of Kafka to understand his personality and private experience. Even this could not give him a tangible interpretation of what is the singular message from The Trial.

\subsection{Symbolic Approaches}

Gregor Kalinowski takes a symbolic view on The Trial. He argues that there has been a symbiotic relation between the two general receptions of The Trial: the symbolic and the autobiographical (Kalinowski, 2010, p.450). He points out the identification of junctures where the real-world events, enter the process of composition. Kalinowski devotes his reading of The Trial to the symbolic objects and events. Through this symbolic reading Kalinowski explains Fräulein Bürstners white blouse as a clean record and clean slate (Kalinowski, 2010, p.450) that K. later yearned after in The Trial. He also interprets the open window in the trial room as the possibility of escape (2010, p.451). He says the moved pictures in Bürstners room means muddled up evidence. He argues that "Alternatively (or additionally), insofar as each photograph captures a single scene, this may be a warning or signal that scenes have been durcheinandergeworfen, that the original sequence of events has been jumbled" (Kalinowski, 2010, p.452). 
Kalinowsi interprets symbols, actions, and episodes in his reading of The Trial. Even though he could not clearly in practical terms mention the point of guilt that holds Joseph K. culpable as the court in The Trial alleges, he still takes a position that evidence abound to prove that $\mathrm{K}$. is guilty. In his words, "K. was indeed caught doing something naughty, and that this is being occluded in and through generation of a more alluring interpretation. His second piece of naughtiness, insisting on his innocence, occasions the trial" (2010, p.457). Kalinowski does more to identify symbolic objects, but one cannot depend on his reading to see into the world of the Protagonist, Joseph K.

Karl J. Kuepper like Kalinowsi examines gestures and postures in The Trial and submits that both postures and gestures come in to give a message in the characters' environment, and some of such similar gestures and postures reappear all through the novel (Kuepper, 1970, p.144). Kuepper interprets some of these gestures as being symbolic. He demonstrates how the gestures/postures in the text are significant in understanding the text. He observes that some of the postures/gestures as ambiguous as they are, communicate deep meaning in the text. Kuepper draws the reader's attention to the gesture of the handshake or hand stretched out for instance, to say that K's. uncle's handshake is dubious, embarrassing and at the end even destructive (1970, p.146).

Kuepper on the other hand highlights the gesture of stooping, which he interprets as being fundamental to understanding the court proceedings, with an instance from K's. bending down to see the painting in Huld's office. He compares this posture with the man from the country who has to peer through the entrance to the law and submits that "insight and self-humiliation are tied together" in this gesture, "and this reflects an essential aspect of K.'s position in the trial" (Kuepper, 1970, p.149). Kuepper focuses his reading to studying and commenting on postures in The Trial; how these postures give meaning to the text and the significance of understanding the postures to appreciate The Trial.

\subsection{Heterologous Readings}

In “One commentator's Despair: Notes on the structure of Kafka's The Trial” Dieter P. Lotze uses The Trial to outline the basic editorial uncertainty surrounding the works of Kafka and to exemplify some of the problems to be solved before making an attempt to interpret Kafka (Lotze, 1977, p.390). Citing the postscript to the first, second and third editions, Lotze raises doubt on the structure of The Trial and points at other scholars' arguments that suggest a change in sequence of the chapters of the text (1977, p.392). Lotze draws attention to factual discrepancies in The Trial, for example, Joseph K.'s uncle first appears as Karl but later refers to himself as Albert (1977, p.393). Lotze compares other scholar's views about the structure of The Trial without necessarily giving a solution on how to solve the problem that lies in understanding the text due to the nature of its structure.

Marc Lucht's study distances from other studies by his subject of interest in the introduction to his book, Kafka's Creatures: Animal, Hybrids, and Other Fantastic Beings. His study is peculiar because Lucht focuses on the presence of non-human creatures in the works of Franz Kafka, showing the significant involvement of nonhuman creatures as the major concerns of Kafka's oeuvre. Such major issues cut across "the nature of authenticity, 
family life, Jewishness, and the nature of language and art" (Lucht, 2010, p.3). Lucht observes the presence of those non-human creatures in Kafka's non-literary writings. He says, the collection of essays in this book helps illuminate the literary and the philosophical significance of Franz Kafka's obsession with non-human animals; how it has shed light on Kafka's themes. Lucht shows that Kafka anticipated in his works some of the recent development in contemporary thinking about non-human animals (2010, p.4).

Lucht holds that recent developments in philosophy and literary theory have worked with ethology in directing scholarly attention to non-human animals (2010, p.6). In his words:

The postmodern philosopher Jacques Derrida, for example, suggests the possibility of a 'deconstruction' of anthropocentric conceptions of human subjectivity. Such deconstruction would disclose both the arbitrariness of the human/animal distinction and that such a distinction ultimately is founded on human self-interest and selfaggrandizement. Indeed, our biased self-interest helps explain the fervency with which thinkers have searched for criteria, such as rationality, tool use, language use, self-awareness, or culture, according to which one can distinguish humanity from and raise it above animality. For Derrida, deconstruction will show that traditional conceptions of subjectivity are grounded in a 'carnophallogocentrism'. (2010, p.6)

The essays on Kafka's creatures generally demonstrate a shift from anthropocentric attitudes to biocentric or ecocentric moral thinking (Lucht, 2010, p.7). They imply that Kafka's works reflected upon human relationship with other animals as it has been a general concern in scholarship today and has led to a renewed sense of the continuities between humanity and animality (2010, p.9). Some of the essays also demonstrate humanity's alienation from its heritage. For instance, Margot Norris in his reading sees Joseph K. and other characters of Franz Kafka as "human-animal victim caught up in an environment designed to stupefy and terrorize him" (2010, p.30).

Thomas H. Ford observes that the Judges' portrait by Titorelli "acquires a third identity, that of the goddess of the hunt, so that justice blurs indistinguishably into pursuit, persecution, triumph, and death" (2010, p.125). Ford says the allegorical attribute of Titorelli's painting also suggests the presence of Hermes (2010, p.125). The emphasis on the presence of Hermes here is to show how The Trial attracts the presence of non-human creatures, including gods.

However, Dean Swinford singles out The Trial among Kafka's works to show that it is liberated from all animal concern. He quotes Deleuze and Guattari as saying: "Kafka's principal animal tales were written just before The Trial or at the same time as it, like a sort of counterpoint to the novel, which liberates itself from all animal concern to the benefit of a much higher concern" (Deleuze \& Guattari, as cited in Swinford, 2010, p.223).

Donna Yarri ends the collection with an index to Kafka's use of creatures in his writings. Yarri gleans through Kafka oeuvre and presents a guide to the location of nonhuman creatures in both fictional and nonfictional writings of Franz Kafka (Yarri, 2010, pp.273-283). 


\section{Conclusion}

Reading Franz Kafka's The Trial through other critical readings creates a profound excitement due to the fact that no generalisation about the text is actually an absolute. Taken from source study, religion, modernist, and symbolic approaches, the critical readings have shown that the text can be approached from both ethical and essential viewpoints. However, the essence of the text is in the text itself; this is seen in some of the readings that have demonstrated that The Trial is not a reflection of any human society but at best a refraction of a certain culture. This goes with implications which may mean that the critique of the text accounts for the language and certain actions that constitute the text. Many studies respond to issues external to The Trial and simply involves the text as a pretext. Yet some studies focus on the text and demonstrate that the external knowledge of the text cannot overshadow its own knowledge which is the essence of the text itself. In other words, a good number of studies have attended to the question of usefulness of the text, in relation to history, politics, etc. while others look at what the text itself is by paying attention to its structures. These available studies on The Trial demonstrate the fact that a literary text is an inexhaustible field for multiple discourses.

\section{References}

[1] Akwanya, A. Nicholas. (2018) Literature and aspects of causality. University of Nigeria Press.

[2] Antinoff, Steve. (2009). Bloodying the cutting edge: (With some help from Kafka) a Zen Koan for dance. Dance Chronicle, 32(3), 353-376. www.jstor.org/stable/25598223

[3] Banakar, Reza. (2010). In search of heimat: A note on Franz Kafka's concept of law. Law and Literature, 22(3), 463-490. https://doi.org/10.1525/lal.2010.22.3.463

[4] Corngold, S. \& Gross, R. V. (2011). Introduction. In S. Corngold \& R. V. Gross (Eds.), Kafka for the twenty-first century (pp.1-23). Boydell \& Brewer-Amden House.

[5] De Coste, Frederick C. (1994). Kafka, legal theorizing and redemption. Mosaic: A Journal for the Interdisciplinary Study of Literature, 27(4), 161-178. www.jstor.org/stable/24775804

[6] Doležel, L. (1983). Intensional function, invisible worlds, and Franz Kafka. Style, 17(2), 120-141. www.jstor.org/stable/42945464

[7] Doreen, Densky. (2011). Proxies in Kafka: Konicipist FK and prokurist Joseph K. In S. Corngold \& R.V. Gross. (Eds.), Kafka for the twenty-first century (pp. 120135). Boydell \& Brewer-Amden House.

[8] Fleming, C. \& J. O’Carroll. (2011). Delusions of agency: Kafka, imprisonment, and modern victimhood, in K. A. Kordela \& D. Vardoulakis (Eds.), Freedom and confinement in modernity: Kafka's cages (pp. 29-48). Macmillan-Palgrave. 
[9] Ford, Thomas H. (2010). Crowds, animality, and aesthetic language in Kafka's 'Josephine'. In M. Lucht \& D. Yarri (Eds.), Kafka's Creatures: Animals, Hybrids, and Other Fantastic Beings (pp.119-159). Rowman \& Littlefield-Lexington Books.

[10] Fort, K. (1964). The function of style in Franz Kafka's the trial. The Sewanee Review, 72(4), 643-651. www.jstor.org/stable/27541062

[11] Kalinowski, G. (2010). "Fräulein bürstners weiße bluse": Making sense stick in Kafka's the trial.' The German Quarterly, 83(4), 449-464. www.jstor.org/stable/40928939

[12] Kordela, A. K. \& Vardoulakis, D. (2011). Introduction. In K. A. Kordela \& D. Vardoulakis (Eds.), Freedom and confinement in modernity: Kafka's cages (pp. 16). Macmillan-Palgrave.

[13] Kordela, A. K. (2011). Kafkaesque: (Secular) kabbalah and allegory. In K. A. Kordela \& D. Vardoulakis (Eds.), Freedom and confinement in modernity: Kafka's cages (pp.128-158). Macmillan-Palgrave.

[14] Kuepper, K. J. (1970). Gesture and posture as elemental symbolism in Kafka's the trial. A Journal for the Interdisciplinary Study of Literature, 3(4),143-152. www.jstor.org/stable/24776239

[15] Lotze, P. D. (1977). One commentator's despair: Notes on the structure of Kafka's the trial. Journal of Modern Literature, 6(3), 389-397. www.jstor.org/stable/3831183

[16] Lucht, M. (2010). Introduction. In M. Lucht \& D. Yarri (Eds.), Kafka's creatures: Animals, hybrids, and other fantastic beings (pp. 3-16). Rowman \& LittlefieldLexington Books.

[17] Norris, M. (2010). Kafka's hybrids: Thinking animals and mirrored humans. In M. Lucht \& D. Yarri (Eds.), Kafka's Creatures: Animals, Hybrids, and Other Fantastic Beings. Rowman \& Littlefield-Lexington Books.

[18] Posner, R. A. (2010). Kafka: The writer as lawyer. Columbia Law Review, 110(1), 207-215. www.jstor.org/stable/40380327

[19] Rahv, P. (1939). Franz Kafka: The hero as lonely man. The Kenyon Review, 1(1), 6074. www.jstor.org/stable/4332044

[20] Swinford, D. (2010). The portrait of an armor-plated sign: Reimagining samsa's exoskeleton. In M. Lucht \& D. Yarri (Eds.), Kafka's creatures: Animals, hybrids, and other fantastic beings (pp 211-236). Rowman \& Littlefield-Lexington Books.

[21] Ward, B. K. (2004). Giving voice to Isaac: The sacrificial victim in Kafka's trial.' Shofar, 22(2), 64-84. www.jstor.org/stable/42943636 
[22] Yarri, D. (2010). Index to Kafka's use of creatures in his writings. In M. Lucht \& D. Yarri (Eds.), Kafka's creatures: Animals, hybrids, and other fantastic beings (pp. 269-283). Rowman \& Littlefield-Lexington Books. 